\title{
Dynamics of Transformation of Small FCC Crystal into Icosahedral Nanoparticles
}

\author{
V. Beloshapka ${ }^{1}$, A. Melnick ${ }^{2}$, V. Soolshenko², D. Pimenov ${ }^{1}$ \\ 1 Berdyansk State Pedagogical University, 4, Schmidt St., 71100 Berdyansk, Ukraine \\ ${ }^{2}$ G.V. Kurdyumov Institute for Metal Physics, N.A.S. of Ukraine, 36, Academician Vernadsky Blvd., \\ 03142 Kyiv, Ukraine
}

(Received 16 July 2021; revised manuscript received 20 October 2021; published online 25 October 2021)

\begin{abstract}
The temperature stability of nanoparticles of such FCC metals as $\mathrm{Ni}, \mathrm{Cu}, \mathrm{Au}, \mathrm{Ag}, \mathrm{Pt}, \mathrm{Pd}, \mathrm{Al}, \mathrm{Pb}$ was studied by the molecular dynamics method using EAM potentials. It was established that small-size particles of all the above-mentioned metals with an FCC structure are unstable and transform into Icosahedral (Ic) structures. During the FCC - Ic transformation, an abrupt decrease in potential energy was observed in the temperature dependence of the potential energy. After this transformation, the formed Ic structures remained stable in the entire temperature range up to melting. The data on the temperature and value of the potential energy jump $\mathrm{dE}$ during the transformation of structures with different numbers of atoms for the metals studied were calculated. The surface free energy of the structures was determined before the transformation. In addition, the potential energy distributions of atoms were found immediately before and after the transformation. The loss of stability with a decrease in the size of a nanoparticle is due to an increase in its specific surface free energy. The transformation of structures was accompanied by a decrease in the surface free energy of nanoparticles, which exceeds the increase in the volume elastic energy. The structure transformation mechanism was studied. The transformation of the structure is realized by deformation and rotation of tetrahedra, into which the FCC cluster can be divided. For all metals studied, the structure transformation mechanism is universal and is of collective and diffusionless nature. The duration of structure transformation for all structures studied did not exceed $10-10$ of a second.
\end{abstract}

Keywords: Instability, Icosahedral structure, Surface energy, Size effect, Structure transformation.

\section{INTRODUCTION}

At present, nanosystems, due to the uniqueness of their physicochemical properties, are widely used in technologies. The uniqueness of nanosystems is caused by a significant change in the existing physical properties and the emergence of completely new ones with a decrease in the characteristic dimension of the system. At the same time, the stability of nanosystems and, in particular, nanoclusters, is one of the main characteristics that determine the possibility of their effective implementation in modern technologies. The loss of stability and transformation of metastable structures is a phenomenon that often occurs in the physics of nanosystems [1]. The loss of mechanical stability of a nanosystem can be accompanied by both disintegration of an object into smaller clusters and polymorphic phase transformations into them. The mechanisms of structure transformation during these changes are complex and have not been closely examined $[2,3]$. The difficulty in studying the mechanisms of transformation by experimental methods is connected with a very short time of their implementation.

This work is dedicated to the issue of temperature stability of metal nanoclusters of FCC metals. It was convincingly proved both theoretically and experimentally [4-8] that for metal FCC particles of small sizes $(L<100 \AA)$ a single-crystal structure is metastable. A pentagonal structure in the form of an icosahedron (Ic), the facets of which correspond to the (111) surface, is stable for them. Besides, its surface has the lowest surface energy of all the forms with the same number of atoms. The mechanism of structure transformation of particles during the FCC crystal - Ic transformation was studied by the molecular dynamics (MD) method. This method allows to determine the conditions of the lattice stability with temperature change, as well as to study the dynamics of the process of structure transformation.

\section{METHODS OF ATOMISTIC SIMULATIONS}

The MD simulations were carried out using the XMD package [9].

To describe the interatomic interaction in the process of MD simulation, the embedded atom method (EAM) [10] was used, in which the total potential energy of a system consisting of $N$ atoms is represented as the sum of embedding and pairwise interaction energies:

$$
U=\sum_{i=2}^{N} F_{i}\left(\rho_{i}\right)+\sum_{i=2}^{N} \sum_{i>1}^{N} \phi_{i j}\left(r_{i j}\right) ; \rho_{i}=\sum_{i \neq j} f_{i}\left(r_{i j}\right) .
$$

The embedding energy $F_{i}\left(\rho_{i}\right)$ of atom $i$ is defined as a function of the total electron density $\rho_{i}$, which is induced by neighboring atom $j$ at position $r_{i}$. The pairwise interaction of atom $i$ and atom $j$ is determined by the potential $\varphi_{i j}\left(r_{i j}\right)$, where $r_{i j}$ is the distance between atoms.

During the simulation, the system was under constant pressure $p=0 \mathrm{~Pa}$, which was maintained by changing the volume of the working cell. Rescaling of atomic velocities was used to change the temperature. The simulations were carried out with a time step of $2 \cdot 10^{-15} \mathrm{~s}$.

Heating was performed at a rate of $3 \cdot 10^{10} \mathrm{~K} / \mathrm{s}$. The visualization of the structure and the analysis of its dynamics were carried out with the OVITO software [11]. 


\section{RESULTS AND DISCUSSION}

In this work, we studied the stability of clusters with a crystal FCC structure containing up to 1500 atoms of such metals as $\mathrm{Ni}, \mathrm{Cu}, \mathrm{Au}, \mathrm{Ag}, \mathrm{Pt}, \mathrm{Pd}, \mathrm{Al}, \mathrm{Pb}$. The clusters were initially cut out from an ideal bulk FCC structure and had a cuboctahedral shape. The choice of the shape was determined by the following. The icosahedral structure that has $n$ shells contains the so-called magic number of atoms determined by the expression [8]: $N=\left(10 n^{3}+15 n^{2}+11 n+3\right) / 3$. A cuboctahedron can be represented as a cube truncated by 8 planes perpendicular to its main diagonals, so that new facets begin to touch. In this case, the number of atoms in the cuboctahedron with a crystal FCC structure always belongs to the magic numbers of the icosahedron. As it will be shown below, during the FCC crystal - Ic transformation, an Ic that was formed from the cuboctahedron always has a completely filled outer shell. This fact greatly simplifies the calculation of the energy contribution of surface atoms. It should be noted that the mechanism of transformation of the FCC structure in the form of a cube and a cuboctahedron was the same. The numbers of atoms in the structures with a cubic shape do not belong to the series of magic numbers of an icosahedron. In this regard, the difference in the transformation consisted only in the fact that the atoms of the cube, which were cut off from it during the formation of the cuboctahedron, always turned out to be on the outer unfilled shell of the icosahedron.

For the cuboctahedron of all the above-mentioned chemical elements with the magic number of atoms from 13 to 2089, the temperature dependence of the potential energy $E_{p}(T)$ in the range of 0 to the melting point and their structure in this temperature range were studied. For all metals studied, FCC structures with a small number of atoms $(N<1000)$ turn out to be unstable and transform into icosahedra with an ideal pentagonal structure [8]. During the FCC - Ic transformation, an abrupt decrease in potential energy is observed in the $E_{p}(T)$ dependence. The duration of the FCC - Ic transformation process for all structures studied did not exceed $10^{-10}$ of a second. The type of the $E_{p}(T)$ dependence that is characteristic of all structures is shown on the example of $\mathrm{Cu}^{309}$ cluster in Fig. 1. The course of the $E_{p}(T)$ dependence up to the transformation temperature has always been reversible, and the FCC structure of the cuboctahedra persisted indefinitely. After the transformation, the formed Ic structures remained stable in the entire temperature range up to melting.

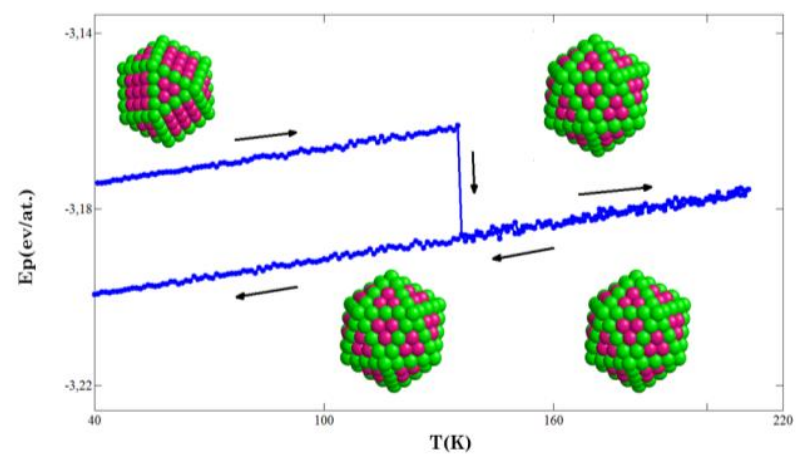

Fig. 1-Temperature dependence of the potential energy $E_{p}(T)$ for the $\mathrm{Cu}^{309}$ structure before and after the $\mathrm{FCC}-\mathrm{Ic}$ transformation

Table 1 combines the data on the temperature and size of the potential energy jump $d E$ during the transformation of structures with different numbers of atoms for the metals studied.

Table 1 - Data on the temperature and value of the potential energy jump $d E$ during the transformation of structures with different numbers of atoms for the metals studied

\begin{tabular}{|c|c|c|c|c|c|c|c|c|}
\hline $\begin{array}{l}\text { Number of } \\
\text { atoms }\end{array}$ & $\begin{array}{c}\mathrm{Cu} \\
T(\mathrm{~K}), \\
d E(\mathrm{eV}) \\
\end{array}$ & $\begin{array}{c}\mathrm{Ni} \\
T(\mathrm{~K}), \\
d E(\mathrm{eV})\end{array}$ & $\begin{array}{c}\mathrm{Au} \\
T(\mathrm{~K}), \\
d E(\mathrm{eV})\end{array}$ & $\begin{array}{c}\text { Pt } \\
T(\mathrm{~K}), \\
d E(\mathrm{eV})\end{array}$ & $\begin{array}{c}\text { Pd } \\
T(\mathrm{~K}), \\
d E(\mathrm{eV})\end{array}$ & $\begin{array}{c}\mathrm{Al} \\
T(\mathrm{~K}), \\
d E(\mathrm{eV})\end{array}$ & $\begin{array}{c}\text { Ag } \\
T(\mathrm{~K}), \\
d E(\mathrm{eV})\end{array}$ & $\begin{array}{c}\mathrm{Pb} \\
T(\mathrm{~K}), \\
d E(\mathrm{eV})\end{array}$ \\
\hline 13 & $1 ; 0.086$ & $1 ; 0.11$ & $1 ; 0.35$ & $1 ; 0.283$ & $1 ; 0.191$ & $1 ; 0.09$ & $1 ; 0.185$ & $1 ; 0.32$ \\
\hline 55 & $1 ; 0.08$ & $1 ; 0.084$ & $1 ; 0.168$ & $1 ; 0.097$ & $1 ; 0.112$ & $1 ; 0.05$ & $1 ; 0.085$ & $1 ; 0.133$ \\
\hline 147 & $1 ; 0.057$ & $22 ; 0.039$ & $252 ; 0.018$ & $876 ; 0.001$ & $292 ; 0.033$ & $372 ; 0.017$ & $1 ; 0.051$ & $142 ; 0.019$ \\
\hline 309 & $135 ; 0.025$ & $414 ; 0.03$ & $459 ; 0.014$ & - & $720 ; 0.023$ & - & $427 ; 0.018$ & $529 ; 0.015$ \\
\hline 561 & $753 ; 0.019$ & $726 ; 0.027$ & - & - & - & - & - & - \\
\hline 923 & $932 ; 0.012$ & - & - & - & - & - & - & - \\
\hline
\end{tabular}

As seen, the cuboctahedron with the largest number of atoms that underwent transformation turned out to be the copper cuboctahedron with 923 atoms.

For clusters containing up to 147 atoms, the transformation occurred athermally, whereas for larger clusters it was thermally activated. For all the studied elements, the value of the potential energy jump $d E$ during the transformation always decreased with the growth of the cluster.

Since the surface of clusters is crucial for the formation of their physical properties and, in particular, their stability, the surface free energy of the structures was determined before the transformation. In addition, the potential energy distributions of atoms were found immediately before and after the transformation.

The specific surface energy $E_{S}$ of the FCC structure was determined according to the expression $[12,13]$ : $E_{S}=\left(E_{\text {cluster }}-E_{\text {bulk }}\right) / A_{\text {cluster }}$, where $E_{\text {cluster }}$ is the potential energy of a free cluster, $E_{\text {bulk }}$ is the potential energy of this cluster when a massive sample is singled out from its bulk, $A_{\text {cluster }}$ is the cluster surface area. The surface energy $E_{S}$ found by this method for the FCC cuboctahedron will practically coincide with the value of the surface tension, since the surface relaxation during its separation from the bulk sample is insignificant. For icosahedra, these quantities differ 
due to the presence of contraction of the surface layer of atoms, as will be shown below.

The found values of the surface energy $E_{S}$ for cuboctahedra indicate that its size dependence is practically absent for clusters with the number of atoms more than 3-5 thousand. With a decrease in the number of atoms, the values of $E_{S}$ increase monotonously, reaching a maximum for the 13-atom cuboctahedron. As an example, Fig. 2 shows the dependence of the normalized surface tension on the number of atoms in the cluster for $\mathrm{Ni}, \mathrm{Cu}$, and $\mathrm{Au}$. For normalization, the absolute values of these quantities were used after the dependence reached the plateau. Therefore, for $\mathrm{Ni}, \mathrm{Cu}$, and $\mathrm{Au}$, they were 1.612, 1.449, and $1.437 \mathrm{~J} / \mathrm{m}^{2}$, respectively. As can be seen, the surface tension increased 2.5-3 times with a decrease in the number of atoms to 13 in the cluster. It should be noted that this character of the $E_{S}(N)$ dependence does not contradict the obtained by A.I. Rusanov [14] linear dependence of surface tension on the radius of small particles of any nature: $\sigma(R)=K R$, where $K$ is a factor of proportionality. This dependence is valid for the value of $\sigma$ averaged over an arbitrarily oriented ensemble of particles, which is not our case. With a change in the size of the cuboctahedron, the number of atoms remains constant: 1) at its vertices, 2) on the edges - in proportion to $R, 3$ ) on the facets $-R^{2}$, and 4 ) in the volume $-R^{3}$. Calculations of the potential energy of atoms at the vertices, on the edges and facets indicate that it does not depend on the size of the cuboctahedron. Therefore, for example, the potential energies of atoms at the vertices of $\mathrm{Ni}$ cuboctahedra with the number of atoms from 13 to 923 differ by no more than $0.03 \%$.

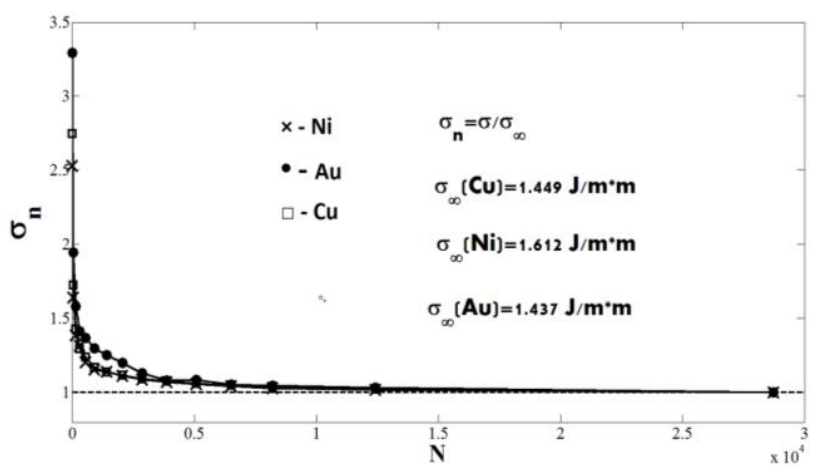

Fig. 2 - Dependence of the normalized surface tension on the number of atoms for $\mathrm{Ni}, \mathrm{Cu}$, and $\mathrm{Au}$ cuboctahedron with the FCC structure

With a decrease in $R$, the fraction of atoms on the vertices and edges relative to their number on the surface increases. At the same time, they have the lowest binding energy among all surface atoms (Fig. 3a). This is the factor that determines the nature of the established dimensional dependence of surface tension.

Fig. 3 shows, for comparison, the potential energy distribution functions immediately before and after the transformation of the $\mathrm{Cu}^{309}$ copper cuboctahedron. In addition, the atomic structures pertaining to different areas of potential energy are shown. As it can be seen, the binding energy of atoms changes in increasing order as follows: atoms at the vertices, on the edges, on the facets and inner shells.
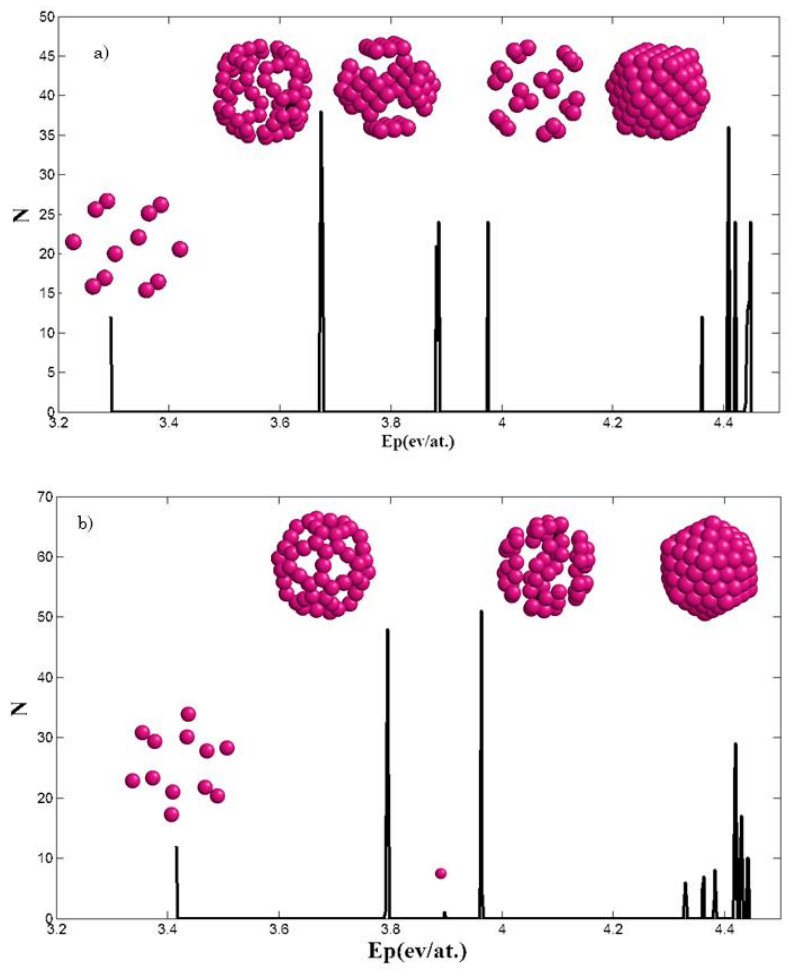

Fig. 3 - The distribution function of atomic potential energy immediately before (a) and after (b) the transformation of the $\mathrm{Cu}^{309}$ copper cuboctahedron into an icosahedron

Estimates of the potential energy of structures during the FCC-Ic transition indicate that the transition is accompanied by a decrease in the surface energy and an increase in the volume elastic energy of the structures.

Besides, the decrease in surface energy always exceeds the volume energy increment. The following leads to a decrease in the surface energy during transformation: 1) a reduction in $E_{\text {pot }}$ of atoms at the vertices while maintaining their number, 2) a decrease in $E_{\text {pot }}$ of each atom on the edges, 3) a increase in the number of atoms on the edges due to the increase in the number of edges from 24 (cuboctahedron) to 30 (Ic), 4) the transformation of (100) surface facets into (111) facets.

Internal contraction stresses during transformation are inhomogeneous and increase towards the center of the structure. For the $\mathrm{Cu}^{309}$ Ic in Fig. 3b, it can be seen that the central atom has changed significantly its $E_{\text {pot }}$ value for this reason.

To analyze the transformation mechanism, the state of the structure during its transformation was recorded step by step. The subsequent visualization of individual segments of the structure made it possible to study their evolution.

To clarify the transformation mechanism, Fig. 4 shows the structure of the cuboctahedron and icosahedron. The cuboctahedron can be represented as consisting of 8 regular tetrahedra and 6 regular quadrangular pyramids with an ideal FCC structure. Each of the quadrangular pyramids, in turn, consists of 2 irregular tetrahedra, the bases of which form the base of the 
pyramid. The vertices of all tetrahedra and pyramids coincide with the center of the cuboctahedron.

Solid angles at the vertices of the regular tetrahedron $\Omega_{\text {tetr, }}$ quadrangular pyramids $\Omega_{\text {pyr }}$ and irregular tetrahedron $\Omega^{*}$ tetr were equal to $0.55129,1.3593$, and $0.6796 \mathrm{sr}$, respectively. The icosahedron, in turn, can be represented as consisting of 20 identical tetrahedra with a solid angle $\Omega_{\text {Ic }}=0.6283 \mathrm{sr}$ at the vertices that coincide with the center of the structure.

Observations of the dynamics of atoms during the transformation of the structure indicate that all 20 tetrahedra in the original structure of the cuboctahedron retain their individuality, turning into 20 identical tetrahedra that form an icosahedron. The transformation mechanism is of collective and diffusionless nature. All atoms belonging to any tetrahedron before the transformation completely form one of the tetrahedron of the icosahedron. a)

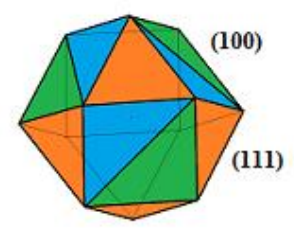

b)

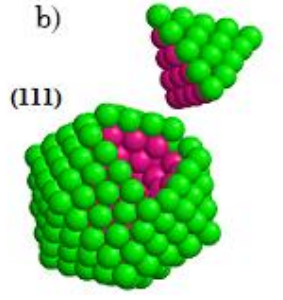

Fig. 4 - Diagram of the structures before (a) and after (b) the transformation

Besides, all tetrahedra before the transformation, having 3 neighboring tetrahedra with a common facet and 6 with common edges, retain their neighbors during the transformation.

The cuboctahedron consists of two types of tetrahedra: 8 regular and 12 irregular ones. The transformation of their structure takes place in different ways: for type one, the solid angle at the vertex increases from $\Omega_{\text {tetr }}$ to $\Omega_{\text {Ic }}$ by $0.077 \mathrm{sr}$. At the same time, all the (111) planes of the tetrahedron are parallel to the base and stretch, retaining their structure. Twelve irregular tetrahedra have a common facet in pairs and bases in the form of isosceles triangles in the (100) plane. During their trans-formation, the solid angles at the vertex decrease from $\Omega^{*}$ tetr to $\Omega_{\text {Ic }}$ by $0.0513 \mathrm{sr}$. Moreover, as a result of contraction in the direction of the common edge at the base of the neighboring tetrahedron, all (100) planes parallel to the base transform into the (111) planes. After that, their common facet turns out to be a twin plane. In addition to the indicated transformations within the tetrahedra of both types, they also rotate around the center of the Ic as integral structures.

Fig. 5 a shows a singled out fragment of the $\mathrm{Ni}^{561}$ cuboctahedron at $T=1 \mathrm{~K}$ that consists of two regular tetrahedra and one quadrangular pyramid between them with a common vertex in the center of the cuboctahedron. Fig. $5 \mathrm{~b}$ shows the same fragment in the Ic after the transformation and cooling to $T=1 \mathrm{~K}$. The vertices of the tetrahedron (Fig. 5a) $\mathrm{O}$ and $\mathrm{O}^{*}$, the center of the cuboctahedron and two edges of the tetrahedron lie on one straight line that, after the trans- formation, turns out to be a fivefold axis of symmetry. The central atom of the cuboctahedron serves as the center of the icosahedron. During the transformation,
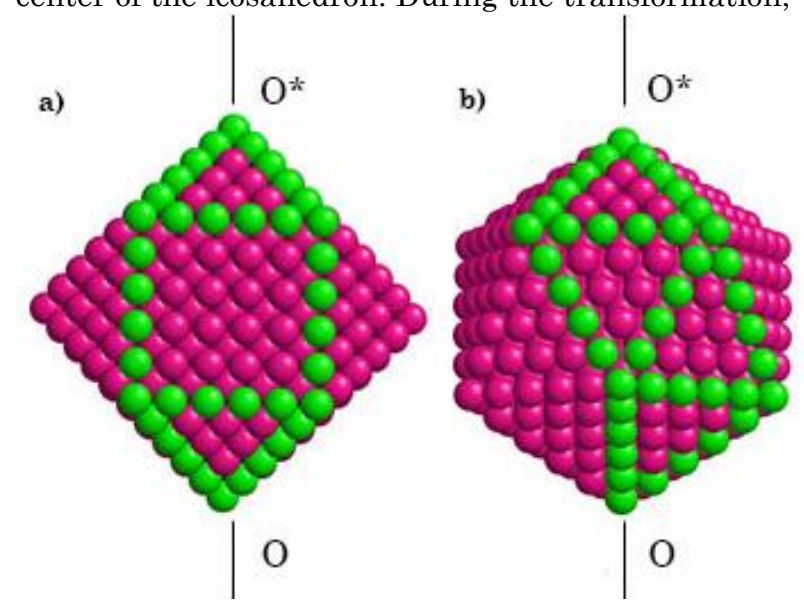

Fig. 5 - The fragment of the FCC structure consisting of two regular tetrahedra and one quadrangular pyramid between them before (a) and after (b) the transformation

the upper and lower tetrahedra rotate relative to each other around the $\mathrm{O}^{*} \mathrm{O}$ axis at an angle of $36^{\circ}$ (Fig. 5b). The dihedral angles of the tetrahedron at the edges of the $\mathrm{O}^{*} \mathrm{O}$ axis increase from $70.53^{\circ}$ to $72^{\circ}$. The choice of the diagonal in the square base of the pyramid that will serve as a new edge of the Ic occurs at random, but it is always consistent with the choice of similar diagonals in the four adjacent bases of the pyramids.

The described transformation mechanism was universal for all studied metals with the number of atoms in clusters indicated in the table.

The observed transformation of structures is caused by the implementation of a "compromise" between the contributions of the excess surface energy and the volume energy of internal stresses. With an increase in the number of atoms in the icosahedron, the number of shells with the (111) tensile facets increases, which leads to an increase in the internal stresses and volume elastic energy of a nanoparticle. The absence of the FCC - Ic transformation in nanoparticles with more than 1000 atoms is caused by an increase in the volume elastic energy comparable to the decrease in the surface energy during the transformation.

\section{CONCLUSIONS}

The conducted study of the temperature stability of nanoparticles of such FCC metals as Ni, Cu, Au, Ag, Pt, $\mathrm{Pd}, \mathrm{Al}, \mathrm{Pb}$ by the MD method, using EAM potentials, allows us to draw the following conclusions:

- small-size nanoparticles of all metals with the FCC structures studied in this work are unstable and transform into icosahedral structures;

- the loss of stability with a decrease in the size of a nanoparticle is due to an increase in its specific surface free energy;

- the FCC - Ic transformation is accompanied by a decrease in the surface free energy of nanoparticles, which exceeds the increase in the volume elastic energy;

- the transformation mechanism is of collective and 
diffusionless nature;

- the rearrangement of the structure during the transformation is realized by deformation and rotation of tetrahedra, into which the FCC cluster can be divided, while preserving individuality in the Ic;

- the mechanism of the FCC-Ic transformation is universal for particles of various sizes of all the metals studied;

- the duration of the transformation for all studied structures did not exceed $10^{-10}$ of a second.

\title{
REFERENCES
}

1. G. Kostorz, Phase transformation in materials (Wiley-VCH: Weinheim: Germany: 2005).

2. J.S. Kim JS, T. Lagrange, B.W. Reed, M.L. Taheri, M.R. Armstrong, W.E. King, N.D. Browning, G.H. Campbell, Science 321, 1472 (2008).

3. L.Q. Chen, Annu. Rev. Mater. Res. 32, 113 (2002).

4. F.D. Fischer, T. Waitz, D. Vollath, N.K. Simha, Prog. Mater. Sci. 53, 481 (2008).

5. H. Hofmeister, Fivefold Twinned Nanoparticles, Encyclopedia of Nanoscience and Nanotechnology 10, 1 (H.S. Nalwa Ed.).

6. L.D. Marks, L. Peng, J. Phys. Cond. Matter. 28, 053001 (2016).

7. H.G. Rubahn, Nanophysik und Nanotechnologie - Teubner, 184 (2004)

8. E.E. Lord, A.L. Makkey, S. Ranganatan, Novaya geometriya dlya novykh materialov, 264 (M.: Fizmatlit: 2010) [In Russian].

9. J.A. Rifkin, XMD-Molecular Dynamics for Metals and Ceramics.

10. Byeong-Joo Lee, Won-Seok Ko, Hyun-Kyu Kim, Eun-Ha Kim, The Modified Embedded-Atom Method Interatomic Potentials and Recent Progress in Atomistic Simulations_CALPHAD, 34 (2010).

11. A. Stukowski, Model. Simul. Mater. Sci. Eng. 18, 015012 (2009).

12. E. Aghemenloh, J.O. Umukoro, S.O. Azi, S. Yusuf, J.O.A. Idiodi, Comput. Mater. Sci. 50, 3290 (2011)

13. S. Ali, V.S. Myasnichenko, E.C. Neyts, Phys. Chem. Chem. Phys. 18, 792 (2016).

14. V.M. Samsonov, A.A. Chernyshova, N.Yu. Sdobnyakov Bull. Russ. Academy Sci.: Phys. 80, 698 (2001).

\section{Динаміка перетворення малих ГЦК кристалів у ікосаедричні наночастинки}

\author{
В. Білошапка ${ }^{1}$ О. Мельник², В. Сульженко르, Д. Піменов ${ }^{1}$ \\ ${ }^{1}$ Бердянський державний педагогічний університет, вул. Шлідта, 4, 71100 Бердянськ, Украӥна \\ 2 Інститут металофізики ілені Г.В. Курдюлова Національної акаделї̈ наук Украӥни, \\ б-р Академіка Вернадського, 36, 03142 Київ, Україна
}

\begin{abstract}
Методом молекулярної динаміки з використанням ЕAM потенціалів вивчена температурна стабільність наночастинок таких ГЦК металів як $\mathrm{Ni}, \mathrm{Cu}, \mathrm{Au}, \mathrm{Ag}, \mathrm{Pt}, \mathrm{Pd}, \mathrm{Al}, \mathrm{Pb}$. Встановлено, що частинки малих розмірів всіх зазначених металів 3 ГЦК структурою $е$ нестабільними i трансформуються в ікосаедричні (Ic) структури. На температурних залежностях потенційної енергії при перебудові ГЦК - Іс спостерігаються стрибкоподібні зменшення потенційної енергії. Сформовані після трансформації Іс структури залишаються стабільними у всьому інтервалі температур до плавлення. Знайдено температури та значення стрибків потенційної енергії $d E$ при трансформації структур з різною кількістю атомів розглянутих металів. Обчислено вільну поверхневу енергію ГЦК структур перед їх перебудовою. Крім цього, знайдено розподіли атомів за потенційною енергіею для структур безпосередньо перед та після їх трансформації. Отримані дані свідчать, що втрата стабільності зі зменшенням розміру структур обумовлена зростанням їх вільної поверхневої енергії. Перетворення структур супроводжуеться зменшенням їх вільної поверхневої енергії на величину, що перевищуе приріст об’емної пружної енергії. Вивчено механізм перебудови. Перебудова реалізуеться через деформацію та обертання тетраедрів, на які може бути розподілена ГЦК структура. Для всіх вивчених металів механізм трансформації структур е універсальним і мае колективний і бездифузійний характер. Тривалість перебудови для всіх вивчених структур не перевищувала $10^{-10}$ секунди.
\end{abstract}

Ключові слова: Нестабільність, Ікосаедрична структура, Поверхнева енергія, Розмірний ефект, Структурна перебудова. 